\title{
Fruit-feeding butterflies assemblage in Deciduous Seasonal Forest fragments and grassland
}

\author{
Marciane Danniela Fleck ${ }^{1 *}$, Ervandil Corrêa Costa ${ }^{1}$
}

'University of Santa Maria, Santa Maria, Brazi

*Corresponding author, email: marcianedanniela@gmail.com

\begin{abstract}
This study aims to investigate the diversity and richness of fruit-feeding butterflies in two fragments of Deciduous Seasonal Forest, with different anthropic explorations, comparing the border and interior environments, and an anthropic area with predominance of grassland, in Taquaruçu do Sul, Rio Grande do Sul, Brazil. Samplings were conducted fortnightly, from August 2012 to July 2013. In each area, were installed attractive traps with a fermented banana and sugarcane juice. In the fragments were installed four traps on the border and four traps 40 meters from the border and in the cultivated pasture area, four traps were also installed. A total of 2,077 specimens of fruit-feeding butterflies were collected, distributed in 45 species and four subfamilies of the Nymphalidae family. The diversity and richness of the fruit-feeding butterflies were higher in the forest fragments. The quantitative cluster analysis segregated the environments into distinct groups, aggregating border environments. By the qualitative analysis there is greater similarity between the fragments. It is concluded that the composition of the fruit-feeding butterflies species is different among the studied areas, and the environments of the forest fragments have similar diversity and richness among them, while the cultivated grassland area is less richness and diversity.
\end{abstract}

Keywords: community, diversity, forest fragmentation, species richness

\section{Introduction}

The conversion of tropical forests into small forest fragments inserted in matrices with predominance of open habitats is a phenomenon that imposes severe threats to the forest ecosystem (Tabarelli et al., 2010). This occurs because the consequences of fragmentation of natural habitats can have adverse effects on species that depend on plants (Leal et al., 2014).

Studies indicate that diversity and composition of butterflies can be altered in human-modified landscapes (Uehara-Prado et al., 2007, Collier et al., 2010, Sant'Anna et al., 2014) and, for this reason, fruit-feeding butterflies are frequently used as indicators of habitat alterations (Bonebrake et al., 2010).

Fruit-feeding butterflies are part of the Nymphalidae family (Lamas, 2004) and are distributed into four subfamilies: Biblidinae, Charaxinae, Nymphalinae and Satyrinae (Wahlberg et al., 2009). This butterfly population can suffer with loss and fragmentation of habitats, specially the creation of habitats affected by borders, due to changes in the microclimate and/or abundance of resources, particularly of host plants or microhabitats associated to forest stratification (Uehara-Prado et al., 2007).

The Decidual Seasonal Forest, in the Alto Uruguai region in Rio Grande do Sul has suffered with the forest fragmentation process, 
among other factors, due to land occupation by European immigrants and the progressive use of soil to implement subsistence cultures, grassland and sawmills (Cunha et al., 2011). Studies with butterflies have been performed in this area, as emphasized by Giovenardi et al. (2013), where butterflies (Lepidoptera: Papilionoidea, Hesperioidea) were collected. However, there are no specific works published for the fruitfeeding butterflies guild that use the attractive traps technique for this region.

In this sense, the objective of this study was to investigate the composition, diversity and richness of fruit-feeding butterflies in two fragments of Decidual Seasonal Forest with different anthropic explorations, by comparing the interior and border environments and an anthropic area with predominance of grassland, in Taquaruçu do Sul, Rio Grande do Sul, Brazil.

\section{Material and Methods}

The study was performed in the municipality of Taquaruçu do Sul, RS, located in the Alto Uruguai region. The representative forest cover in this region is the Decidual Seasonal Forest, since it has deciduous leaves in periods of restrictive climatic factors such as cold, which can affect more than $50 \%$ of forest species from the emerging and the superior canopy (IBGE, 2012). The climate in the region is classified as humid subtropical with hot summer ( $\mathrm{Cfa}$ ) with well distributed rainfall throughout the year and high temperatures in the warmest months (Alvares et al., 2013).

Three distinct areas, two forest fragments and one area of cultivated grassland, were studied in field conditions, being $300 \mathrm{~m}$ apart from each other and having a different history of anthropic exploration. For the differentiation of the areas, the forest fragments were named as follows: degraded (FD), secondary succession (FS) and area with predominance of cultivated grassland (ACG).

The degraded fragment (FD) $\left(27^{\circ} 23^{\prime} 48^{\prime \prime S}\right.$

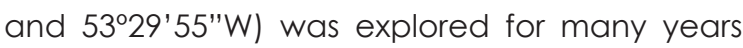
for the removal of timber products in addition to the presence of cattle. During the study period, five trees were removed from the fragment, what originated new clearings. The area has $3.77 \mathrm{ha}$ with a rectangular shape (north-south direction), and maximum width $150 \mathrm{~m}$, given that there is an adjacent agricultural area in the north and the west along the border, a patch of land in the east separated from the fragment by a road, and a plantation of Eucalyptus spp. in the south. In this fragment, there are intermittent streams that fill during periods of high rainfall. It is currently affected, with a reduced number of species and the presence of clearings. Collections were performed in its border and interior, being denominated FDB and FDI, respectively.

The secondary succession fragment (FS)

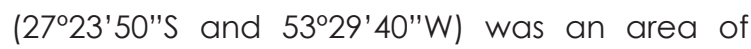
agriculture exploration for several years. In 1980, anthropic action was stopped due to the difficult accessibility, originating a secondary succession forest throughout the years. The fragment area is 2.39 ha with a rectangular shape least-west direction) and maximum width $90 \mathrm{~m}$, with an adjacent agricultural area along the border in the north, east and south directions, and Cynodon spp. grassland in the west. This fragment does not currently have any forest species in a climax stage, but several forest species are going through a regeneration process. Collections were also performed in the border and the interior of this fragment, named FSB and FSI, respectively.

The third area (27\%23'57's and $53^{\circ} 29^{\prime} 43^{\prime \prime} \mathrm{W}$ ) has a history of anthropic exploration from the removal of tress, and a subsequent agricultural exploration around 1970. Presently, the cultivation of exotic grasses such as Cynodon spp. is predominant, with an area of 1 ha. There is agricultural exploration in the adjacent areas, and corn, soy and summer grasslands were cultivated during the study period, with pesticides being subsequently applied. Also, the area was used for grazing dairy cattle during the study period.

Fortnight collections were carried out in each study area, from August 2012 to July 2013, totalling 24 collections. The collection of fruit-feeding butterflies was performed through traps with attractive baits prepared with mashed banana fermented in sugarcane juice for $48 \mathrm{~h}$ in PET bottles.

The modified Van Someren-Rydon traps consisted of a cylinder of black shade material, 
$110 \mathrm{~cm}$ high and $35 \mathrm{~cm}$ diameter, closed on top with clear plastic. This cylinder was fixed to a wood base (where the bait was deposited) attached to steel wires, with an opening of approximately $8 \mathrm{~cm}$ between the cylinder and the base, what allowed the entrance of butterflies in the trap (Figure 1).

Four traps were installed in the fragment border and four traps were installed inside the fragment 40 meters from the border in each forest fragment (degraded - FD, and secondary succession - FS), arranged at north, south, east and west directions, with the traps installed in the border and inside the fragment in each direction. Traps were fixed in the trees with a rope at 1.70 $\mathrm{m}$ above ground. Four traps were installed in the cultivated grassland area and attached to a wood base due to the absence of trees in the site.

In each collection, the traps remained active for two days, being checked every 12 hours for collection in entomological envelopes for the subsequent identification of fruitfeeding butterflies. During the intervals between collections, the traps were maintained in the sites without baits, being inactive.

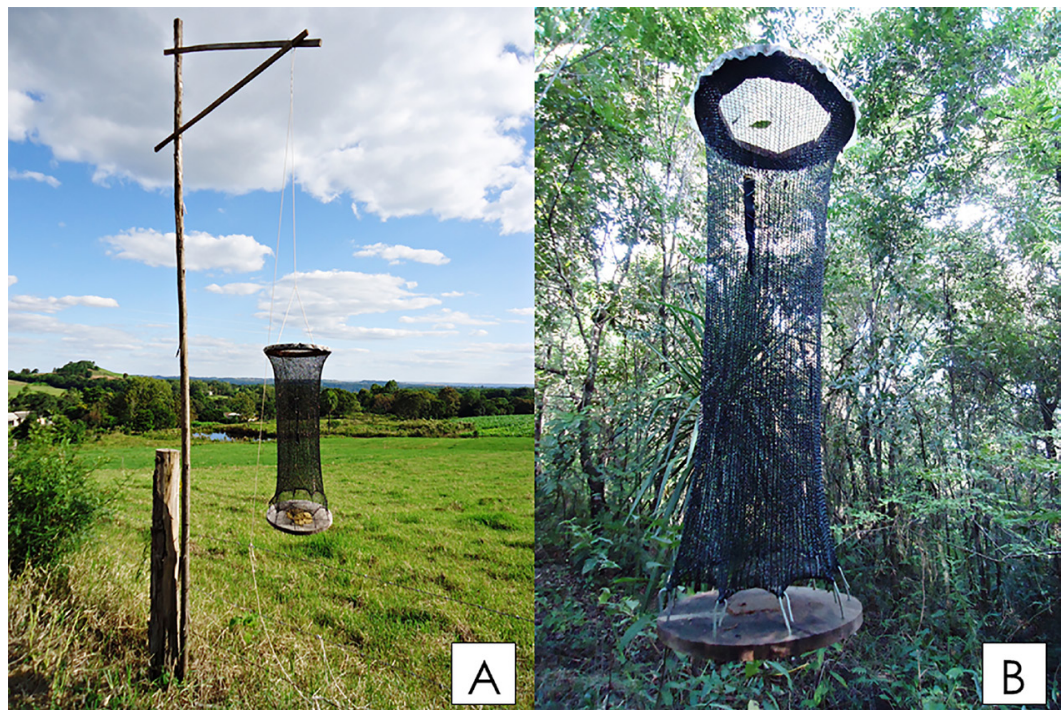

Figure 1. Traps installed in the field, in the cultivated grassland area (A), fixed in wood bases, and in the fragment area (B) fixed in the site trees, in Taquaruçu do SUl, RS, between August 2012 and July 2013

The voucher specimens are deposited in the Laboratório de Entomologia Florestal of Universidade Federal de Santa Maria (UFSM), RS. The species, especially the ones from the Satyrinae subfamily, whose identification was not possible through the comparison with the Scientific Collections, were sent to experts and are deposited in the Zoology Museum of Universidade Estadual de Campinas - ZUEC - LEPIDOPTERA UNICAMP. The taxonomic classification of subfamilies and the species classification followed Wahlberg et al. (2009) and Lamas (2004), respectively.

To assess the diversity of species of fruitfeeding butterflies found in the different areas, a non-parametric a diversity measure was used, calculated with the Shannon index $\left(\mathrm{H}^{\prime}\right)$. Also, Simpson (1-D) and Pielou's evenness (J) indices were verified.
Regarding the similarity of species composition of fruit-feeding butterflies in the different areas, the $\beta$ diversity measure was performed through the calculation of the MorisitaHorn quantitative similarity index (Imh) and the Jaccard qualitative similarity index. Also, a cluster analysis with unweighted average of pair groups (Unweighted Pair Group Method of Arithmetic Mean - UPGMA) was performed, as distance of amalgamation. Both indices and similarities were performed with the statistics software Past version 2.17c (Hammer et al., 2001).

For the study of vegetation, only two forest fragments were considered, since there is no arboreal vegetation in cultivated grassland areas. The method of fixed area was used, with rectangular patches being installed in the fragments. In each patch, all trees with diameter at breast height (1.30 m above round) higher 
than $5 \mathrm{~cm}$ were measured and identified.

In the FD, two sampling units of 1,200 $\mathrm{m}^{2}$ (10 m x $120 \mathrm{~m}$ ) each were randomly delimited, in the east-west direction, consisting of 12 square sub-patches of $100 \mathrm{~m}^{2}(10 \mathrm{~m} \times 10 \mathrm{~m})$, totalling $2,400 \mathrm{~m}^{2}$ of sampled area. As the FS had a smaller area, four sampling units of $600 \mathrm{~m}^{2}(10 \mathrm{~m} \times 60 \mathrm{~m})$ each were defined, in the north-south direction, consisting of six sub-patches of $100 \mathrm{~m}^{2}(10 \mathrm{~m} \times 10$ $m)$, thus totalling the same sampling area as FD.

The system of botanical classification adopted for angiosperms was proposed by the Angiosperm Phylogeny Group (APG III, 2009). The scientific names of forest species were verified in the List of Species of Brazilian Flora (Reflora, 2017) and the Missouri Botanical Garden (Tropicos, 2017). To assess the forest species diversity in the different areas, the indices of Shannon ( $\left.\mathrm{H}^{\prime}\right)$, Simpson (1-D), and Pielou's evenness (J) were used.

The data regarding microclimatic variables of temperature, relative humidity and rainfall were obtained at the automatic meteorological station in Frederico West phalen, RS, $6 \mathrm{Km}$ from the study areas. Values of temperature and relative humidity were obtained with the daily averages, and rainfall values were obtained by the sum of the total millimetres.

The spearman correlation between the number of specimens of butterflies and the average of meteorological variables of temperature $\left({ }^{\circ} \mathrm{C}\right.$ ) and air humidity (\%) and total rainfall was calculated in the Action supplement of Microsoft Excel ${ }^{\circledR}$.

\section{Results and Discussion}

In the period between August 2012 and July 2013, 2,077 fruit-feeding butterflies were captured, all belonging to the Nymphalidae family, and distributed into 4 subfamilies, 11 tribes, 31 genera, and 45 species. When compared to the other subfamilies, Satyrinae (20) concentrated the highest number of species, followed by Biblidinae (17), Charaxinae (7) and Nymphalinae (1) (Table 1).

Table 1. Species of fruit-feeding butterflies collected in an area of cultivated grassland (ACG), interior of a degraded fragment (FDI), border of a degraded fragment (FDB), interior of a secondary succession fragment (FSI), border of a secondary succession fragment (FSB), in Taquaruçu do Sul, RS, from August 2012 to July 2013

\begin{tabular}{|c|c|c|c|c|c|}
\hline \multirow{2}{*}{ Family/Subfamily/Tribe/Species } & \multicolumn{5}{|c|}{ Areas } \\
\hline & ACG & FDI & FDB & $\mathrm{FSI}$ & FSB \\
\hline \multicolumn{6}{|l|}{ NYMPHALIDAE } \\
\hline \multicolumn{6}{|l|}{ BIBLIDINAE } \\
\hline \multicolumn{6}{|l|}{ AGERONIINI } \\
\hline Hamadryas amphinome amphinome (Linnaeus, 1767) & 0 & 2 & 0 & 0 & 2 \\
\hline Hamadryas epinome (C.Felder \& R.Felder, 1867)* & 3 & 62 & 74 & 55 & 54 \\
\hline Hamadryas februa februa (Hübner, [1823]) & 3 & 5 & 10 & 8 & 15 \\
\hline Hamadryas fornax fornax (Hübner, [1823]) & 2 & 10 & 7 & 1 & 1 \\
\hline \multicolumn{6}{|l|}{ BIBLIDINI } \\
\hline Biblis hyperia nectanabis (Fruhstorfer, 1909) & 5 & 30 & 39 & 13 & 29 \\
\hline \multicolumn{6}{|l|}{ CATAGRAMMINI } \\
\hline Callicore hydaspes (Drury, 1782)* & 0 & 7 & 11 & 1 & 0 \\
\hline Callicore pygas thamyras (Ménétriés, 1857) & 0 & 0 & 1 & 0 & 1 \\
\hline Diaethria candrena candrena (Godart, [1824]) & 2 & 4 & 4 & 2 & 2 \\
\hline Diaethria clymena meridionales (H. Bates, 1864) & 1 & 0 & 1 & 0 & 0 \\
\hline \multicolumn{6}{|l|}{ CATONEPHELINI } \\
\hline Catonephele numilia neogermanica Stichel, 1899 & 0 & 1 & 2 & 1 & 1 \\
\hline Cybdelis phaesyla (Hübner, [1831])* & 0 & 1 & 1 & 1 & 1 \\
\hline Eunica eburnea Fruhstorfer, 1907\# & 1 & 0 & 0 & 0 & 0 \\
\hline Eunica tatilla bellaria Fruhstorfer, 1908* & 1 & 0 & 0 & 7 & 3 \\
\hline Myscelia orsis (Drury, 1782) & 0 & 20 & 3 & 12 & 7 \\
\hline \multicolumn{6}{|l|}{ EPIPHILINI } \\
\hline Epiphile hubneri Hewitson, 1861 & 0 & 5 & 10 & 9 & 9 \\
\hline Epiphile orea orea (Hübner, [1823])* & 0 & 2 & 4 & 7 & 4 \\
\hline Temenis laothoe meridionalis Ebert, $1965^{*}$ & 4 & 6 & 5 & 2 & 0 \\
\hline \multicolumn{6}{|l|}{ CHARAXINAE } \\
\hline ANAEINI & & & & & \\
\hline
\end{tabular}




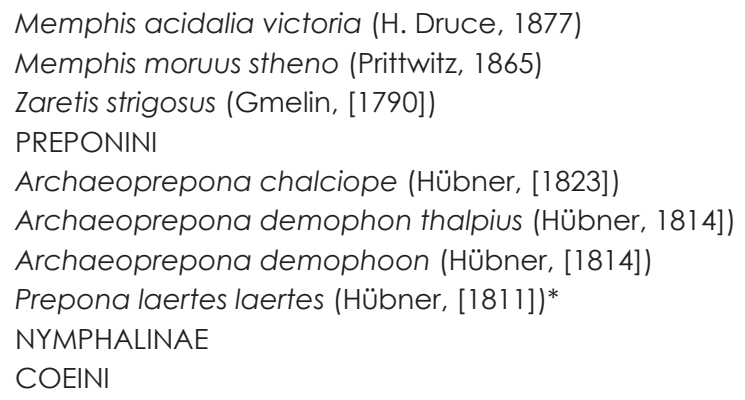

Smyrna blomfildia blomfildia (Fabricius, 1781)

SATYRINAE

BRASSOLINI

Blepolenis catharinae (Stichel, 1902)

Caligo brasiliensis (C. Felder, 1862)

Opsiphanes invirae amplificatus Stichel, 1904

MORPHINI

Morpho helenor achillides C. Felder \& R. Felder, 1867

SATYRINI

Carminda griseldis (Weymer, 1911)*

Euptychoides castrensis (Schaus, 1902)*

Forsterinaria necys (Godart, [1824])*

Godartiana muscosa (Butler, 1870)*

Hermeuptychia sp.*

Moneuptychia soter (A. Butler, 1877)*

Pareuptychia ocirrhoe (Fabricius, 1776)*

Paryphthimoides phronius (Godart, [1824])*

Paryphthimoides poltys (Prittwitz, 1865)*

Pharneuptychia sp.*

Splendeuptychia libitina (A. Butler, 1870)*

Taygetis tripunctata Weymer, 1907*

Taygetis ypthima Hübner, [1821]*

Yphthimoides affinis (A. Butler, 1867)*

Yphthimoides ordinaria Freitas, Kaminski \& Mielke, 2012*

Yphthimoides sp.*

Abundance (N)

Richness (S)

Shannon index (H')

Simpson index (1-D)

$\begin{array}{ccccc}19 & 23 & 36 & 31 & 36 \\ 15 & 40 & 60 & 44 & 56 \\ 1 & 6 & 6 & 3 & 3\end{array}$

1

0

0

1

$\begin{array}{lll}1 & 0 & 0\end{array}$

45

6

3
0

\section{6}

Pielou's evenness (J)

$\begin{array}{lllll}11 & 24 & 60 & 43 & 47\end{array}$

species that are deposited at Universidade Federal de Santa Maria an

Although the two forest fragments analysed have reduced territory extension and a history of anthropic exploration, they still nest a higher richness of species of fruitfeeding butterflies in comparison to other studies performed in other forest formations in Rio Grande do Sul. Roman et al. (2010) recorded 21 species in a native forest remnant in São Sepé, RS; Pedrotti et al. (2011) collected 30 species in a mixed ombrophilous forest in São Francisco de Paula, RS; and Silva et al. (2013) collected 16 species in the Horto Botânico Irmão Teodoro Luis, RS. This richness of fruit-feeding butterflies is an indicator of the importance of the conservation of forest fragments, however small their territory extension, as is the case of the studied forest areas.

When analysing the richness of fruitfeeding butterflies in each studied area, it was verified that the lowest richness was recorded in the cultivated grassland area (ACG) when compared to the other areas that have arboreal vegetation. The highest richness was found in the border environment of the degraded fragment (FDB), followed by the interior of this fragment (FDI), with 38 and 36 species, respectively. In the secondary succession fragment, the total of species recorded was 31 in the border (FSB) and 30 in the interior (FSI) (Figure 2). Thus, it is evidenced that the richness of the border and interior environments of the same fragment are 
similar between each other, and this might have occurred because the fragments are influenced by the border effect in the whole fragment area due to their small territory extension.

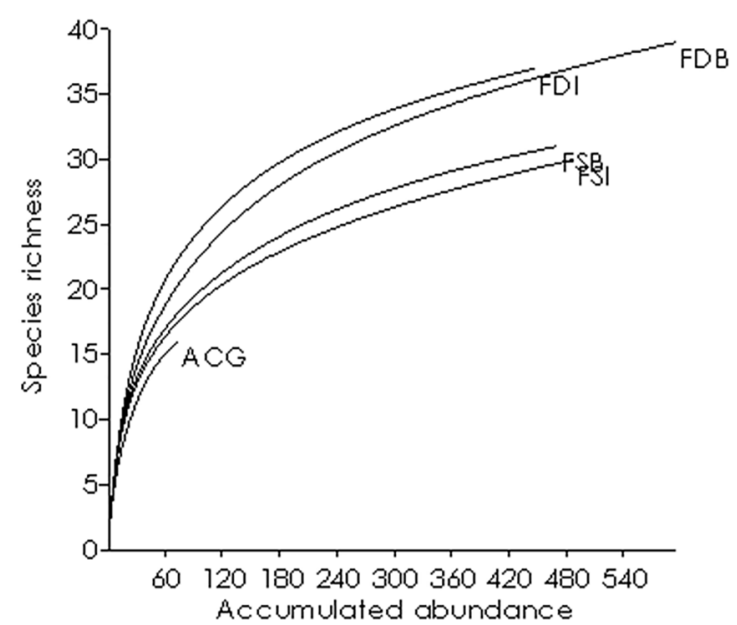

Figure 2. Analysis of rarefaction of fruit-feeding butterflies in the five studied sites. Abbreviations represent the five types of habitat: cultivated grassland area (ACG), interior of degraded fragment (FDI), border of degraded fragment (FDB), interior of secondary succession fragment (FSI), border of secondary succession fragment (FSB), in Taquaruçu do Sul, RS, between August 2012 and July 2013

It was verified that, even though the richness of fruit-feeding butterflies in the interior and border environments of the same fragment was similar, the interior environment still facilitates the development of certain species such as Caligo brasiliensis (C. Felder, 1862), Yphthimoides affinis (A. Butler, 1867) and Opsiphanes invirae amplificatus Stichel, 1904, which were found exclusively in this environment (Table 1). As emphasized by Freitas (2010), it suggests that butterfly communities that persist in these remnants are the result of a new balance found after the conversion of these habitats.

While analysing three forest habitats, Filgueiras et al. (2016) found a higher abundance of fruit-feeding butterflies in small fragments and in the forest border in comparison with the fragment interior. Thus, the authors concluded that although the establishment of landscapes modified by anthropic actions probably result in the local extinction of species dependent on the forest, it allows the persistence of species adapted to disturbances. In this sense, small forest fragments are able to keep butterfly diversity with the most abundant species, typical of the forest border, open and disturbed areas (Ribeiro et al., 2012).

In a study performed in three restored areas with different ages in a native forest, Sant'Anna et al. (2014) verified that fruitfeeding butterfly communities reveal patterns of substitution of successional species. It indicates that as the diversity of forest species increases throughout the restoration period, butterfly species that are used to grasslands and forest borders have their abundance and richness decreased.

Regarding the values of Shannon diversity and Pielou's evenness, the interior and border environments of the two forest fragments analysed were similar. The cultivated grassland area (ACG), on the other hand, showed a lower diversity in relation to the other areas $\left(H^{\prime}=2.28\right)$, whereas the highest Shannon diversity was found in the interior of the degraded fragment (FDI) ( $\mathrm{H}^{\prime}$ = 3.00) (Table 1).

The cultivated grassland area (ACG), in addition to having the lowest Shannon diversity, also showed the lowest Simpson index (1-D = 0.86). In the forested areas, however, the value was higher and similar among the environments. The ratio between the diversity obtained and the maximum diversity achieved, in case all species were equally abundant, resulted in Pielou's evenness. From the five environments analysed, FDI showed the highest evenness value $(\mathrm{J}=0.83)$, 
indicating that $83 \%$ of the maximum theoretical diversity was achieved by the sampling method used, followed by the ACG fragment $(J=0.82)$. The lowest values were found in the FDB and FSI environments, with 0.79 in both areas.

In a study performed in a transition area of the Pampa biome with Atlantic forest, Spaniol \& Morais (2015) found higher population densities of Satyrini in the Pampa biome, where the predominant vegetation was grass from the Poaceae family. Nearly all Satyrinae caterpillars feed from Poaceae, including bamboo, or Cyperaceae (Brown, 1992; Brown \& Freitas, 2000).

In the present study, however, the presence of fruit-feeding butterflies of the Satyrinae subfamily in the forest fragments and their low occurrence in the cultivated grassland area can be explained by the small territorial extension of the latter, the non-predominant native grass vegetation, and the area not being included in the Pampa biome. Another aspect to be considered is that the habitat of caterpillars from fruit-feeding butterflies of the Satyrinae subfamily is the forest border environment, even though they feed on grass (Brown \& Freitas, 2000), and due to the proximity between the studied areas, adult butterflies can easily move.

The forest species found in the two forest fragments analysed (Table 2) can explain the greater abundance and richness of butterflies in the forested areas in comparison to the cultivated grassland area, since the presence of plants provides shelter and food for young and adult Nymphalidae. It is evidenced by the specificity of butterflies with host plants, making them good indicators of the vegetal composition of a given site, since their presence depends on the availability of food resources for caterpillars (Santos et al., 2016).

Table 2. Relationship of forest species sampled in a degraded (FD) and a secondary succession (FS) fragment, in Taquaruçu do Sul, RS, between August 2012 and July 2013

\begin{tabular}{|c|c|c|c|}
\hline Family & Species & $\mathrm{FD}$ & FS \\
\hline Annonaceae & Annona neosalicifolia H. Rainer & - & 4 \\
\hline Arecaceae & Syagrus romanzoffiana (Cham.) Glassman & - & 1 \\
\hline \multirow[t]{3}{*}{ Boraginaceae } & Cordia americana (L.) Gottschling \& J.S.Mill. & - & 10 \\
\hline & Cordia ecalyculata Vell. & - & 3 \\
\hline & Cordia trichotoma (Vell.) Arráb. ex Steud. & - & 10 \\
\hline \multirow[t]{2}{*}{ Cannabaceae } & Celtis sp. & 1 & - \\
\hline & Trema micrantha (L.) Blume & 1 & - \\
\hline Celastraceae & Pristimera andina Miers & 1 & - \\
\hline Ebenaceae & Diospyros inconstans Jacq. & 5 & 21 \\
\hline \multirow[t]{4}{*}{ Euphorbiaceae } & Actinostemon concolor (Spreng.) Müll.Arg. & 4 & - \\
\hline & Manihot grahamii Hook. & - & 1 \\
\hline & Sebastiania brasiliensis Spreng. & 1 & - \\
\hline & Sebastiania commersoniana (Baill.) LB Sm. \& Downs & - & 3 \\
\hline \multirow[t]{10}{*}{ Fabaceae } & Ateleia glazioviana Baill. & - & 17 \\
\hline & Bauhinia forficata Link & - & 1 \\
\hline & Calliandra brevipes Benth. & 1 & - \\
\hline & Erythrina falcata Benth. & 7 & 3 \\
\hline & Holocalyx balansae Micheli & 3 & - \\
\hline & Inga marginata Willd. & 15 & 3 \\
\hline & Lonchocarpus campestris Mart. ex Benth. & 4 & 53 \\
\hline & Lonchocarpus nitidus (Vogel) Benth. & - & 5 \\
\hline & Machaerium paraguariense Hassl. & 3 & 55 \\
\hline & Parapiptadenia rigida (Benth.) Brenan & - & 10 \\
\hline \multirow[t]{4}{*}{ Lauraceae } & Nectandra megapotamica (Spreng.) Mez & 9 & 1 \\
\hline & Ocotea diospyrifolia (Meisn.) Mez & 1 & - \\
\hline & Ocotea puberula (Rich.) Nees & 12 & 21 \\
\hline & Ocotea sp. & - & 1 \\
\hline Malvaceae & Luehea divaricata Mart. & - & 39 \\
\hline \multirow[t]{3}{*}{ Meliaceae } & Cabralea canjerana (Vell.) Mart. & 4 & - \\
\hline & Cedrela fissilis Vell. & 3 & - \\
\hline & Guarea macrophylla Vahl & 1 & - \\
\hline
\end{tabular}




\begin{tabular}{llcc} 
& Trichilia catigua A. Juss. & 1 & - \\
& Trichilia clausseni C.DC. & 1 & - \\
& Trichilia elegans A. Juss. & 3 & 1 \\
Moraceae & Sorocea bonplandii (Baill.) W.C. Burger Lanj. \&. Wess. bôer & 14 & - \\
Myrtaceae & Myrcianthes pungens (O.Berg) D. Legrand & 3 & - \\
Phytolaccaceae & Phytolacca dioica L. & 3 & - \\
Primulaceae & Myrsine laetevirens (Mez) Arechav. & - & 14 \\
Rhamnaceae & Hovenia dulcis Thunb. & - & 1 \\
Rosaceae & Prunus myrtifolia (L.) Urb. & - & 2 \\
Rutaceae & Balfourodendron riedelianum (Engl.) Engl. & 5 & - \\
& Helietta apiculata Benth. & - & 26 \\
& Pilocarpus pennatifolius Lem. & 1 & - \\
& Zanthoxylum caribaeum Lam. & - & 6 \\
Salicaceae & Banara tomentosa Clos & - & 1 \\
& Casearia decandra Jacq. & - & 1 \\
Sapindaceae & Casearia sylvestris Sw. & 1 & 6 \\
& Cupania vernalis Cambess. & 15 & 48 \\
Solanaceae & Matayba elaeagnoides Radlk. & - & 1 \\
Sapotaceae & Solanum mauritianum Scop. & 6 & - \\
Verbenaceae & Chrysophyllum marginatum (Hook. \& Arn.) Radlk. & 4 & 1 \\
Urticaceae & Aloysia virgata (Ruiz \& Pav.) Juss. & 3 & 47 \\
\hline Abundance (N) & Urera baccifera (L.) Gaudich. ex Wedd. & 1 & - \\
Richness (S) & & 137 & 417 \\
Shannon index (H') & & 32 & 33 \\
Simpson index (1-D) & & 3.07 & 2.78 \\
Pielou's evenness (J) & & 0.94 & 0.92 \\
\hline
\end{tabular}

Regarding the number of sampled trees, the secondary succession fragment showed a higher number compared to the degraded fragment, what resulted in a lower diversity value for Shannon, Simpson, and Pielou's evenness due to the dominance of certain forest species. This difference in number of trees in the two forest fragments can be explained by the different anthropic explorations they underwent throughout their formation.

Nevertheless, the richness of forest species was similar between the two forest fragments studied, what can be related to the similar richness and diversity of fruit-feeding butterflies in these areas, differing from the cultivated grassland area, that does not have arboreal vegetation. Thirty-two forest species were recorded in the FD, distributed into 17 families, with 20 species being exclusive to this fragment. The FS showed 33 species in 17 families, with 21 exclusive species (Table 2).

Among the species of fruit-feeding butterflies that are indicators of the vegetal composition, we can cite caterpillars of Diaethria clymena meridionales (H. Bates, 1964) that feed from the vegetal species Trema micrantha (L.)
Blume (Cannabaceae); caterpillars of Smyrna blomfildia blomfildia (Fabricius, 1781) in Urera spp. (Urticaceae); caterpillars of Prepona laertes laertes (Hübner, [1811]) in Inga spp. and other leguminous plants; and caterpillars of Zaretis strigosus (Gmelin, [1790]) in Casearia spp. (Salicaceae) (Brown, 1992). The fruit-feeding butterfly Memphis moruus stheno (Prittwitz, 1865 ) is the caterpillar of the botanical families Lauraceae (Brown, 1992) and Piperaceae (Brown \& Freitas, 2000).

The species Eunica eburnea Fruhstorfer, 1907 was collected only in the cultivated grassland environment, with only one individual. According to Brown \& Freitas (2000), the habitat of this species is the forest border and their food resource is the family Euphorbiaceae. This species may have been collected in the cultivated grassland area due to the proximity between the areas, what allows the movement of fruit-feeding butterflies between the areas, and because the botanical family is present in the studied forest fragments, being a food source for caterpillars.

The qualitative and quantitative cluster analyses evidenced distinguishing results between each other. In relation to quantitative 
similarity with the Morisita-Horn index (Imh), it was evidenced that there was a higher coexistence of species of fruit-feeding butterflies in the border of the degraded (FDB) and secondary succession (FSB) fragments. The qualitative index of Jaccard evidenced higher species similarity between the environments of the same fragment, since the environments of the degraded fragment have more qualitative similarity of fruit-feeding butterflies (Figure 3), what can be explained by the composition of fruit-feeding butterflies, the floristic constitution and distinguishing physiognomy of each fragment.

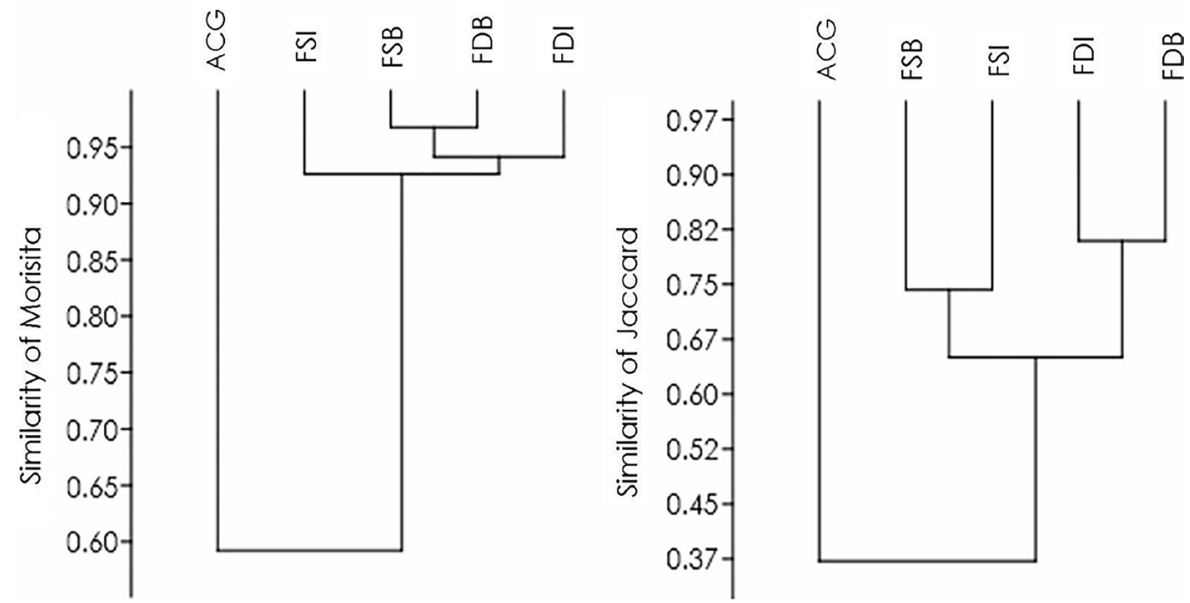

Figure 3. Dendrograms produced from the cluster analysis using the similarity of specific composition of fruit-feeding butterflies obtained by the Morisita-Horn (Imh) similarity index and Jaccard similarity index, among the areas of anthropic action (ACG), degraded fragment interior (FDI), degraded fragment border (FDB), interior of secondary succession fragment (FSI), border of secondary succession fragment (FSB), in Taquaruçu do Sul, RS, between August 2012 and July 2013

Regarding the Spearman correlation between the number of specimens of butterflies and the average of meteorological variables of temperature $\left({ }^{\circ} \mathrm{C}\right)$ and relative humidity (\%) and the total rainfall ( $\mathrm{mm})$, there was a significant correlation only for temperature $\left(r_{s}=0.794, p<0.01\right)$. Therefore, the period with highest temperatures evidenced a higher number of butterflies collected. In the Serra do Japi, according to Brown (1992), an annual cycle of butterflies starts with the first days of high temperatures, in September, occasionally followed by rains, what favour the regrowth of several plants important for feeding adult butterflies and caterpillars.

Although the study was performed in a small area, the guild of fruit-feeding butterflies was rich, providing results for the Alto Uruguai region, in Rio Grande do Sul, emphasizing the importance of the preservation of these fragments. In this context, the maintenance of the biological diversity must be promoted by the legislation at local, regional and national levels through the maintenance of the remnant habitats (Freitas, 2010).

\section{Conclusions}

Species composition, diversity and richness of fruit-feeding butterflies are different in two fragments of Decidual Seasonal Forest, with distinct anthropic explorations and the area of cultivated grassland.

The environments of border and interior of the two forest fragments studied did not show differences in diversity and richness of fruitfeeding butterflies between each other.

The cultivated grassland area showed the smallest richness and diversity of fruit-feeding butterflies in relation to the two forest fragments with distinct anthropic explorations.

\section{Acknowledgements}

We would like to thank the landowners Paulo Pessotto, Guilherme Sponchiado and Hermes Pessotto for authorizing to use their land for study; Ricardo Pessotto for the helping hand in all collections; Forest Engineer MSc. Hadson Hoffer for the help in the laboratory; Professor Dr. André Victor Lucci Freitas from UNICAMP; biologist MSc. Vanessa Schaeffer Pedrotti; Professor Dr. Ana Luiza Gomes Paz from Instituto Federal de 
Educação, Ciência e Tecnologia Farroupilha, campus São Vicente do Sul, for helping to identify fruit-feeding butterflies; Professor Dr. Ana Beatriz Barros de Morais from UFSM for helping in the comparison of my specimens of fruitfeeding butterflies with the Reference Collection from Laboratório de Interações Inseto-Planta do Departamento de Biologia; Professor Dr. Luciano Denardi from UFSM; and the Forest Engineer MSc. Maurício Figueira for helping with the identification of forest species. Also, the first author would like to thank CAPES for the research grant, and the second author would like to thank CNPQ for the research productivity grant.

\section{References}

Alvares, C.A., Stape, J.L., Sentelhas, P.C., Gonçalves, J.L. de M., Sparovek, G. 2013. Köppen's climate classification map for Brazil. Meteorologische Zeitschrift 22: 711-728.

APG 1II. 2009. An update of the Angiosperm Phylogeny Group classification for the orders and families of flowering plants: APG III. Botanical Journal of the Linnean Society 161: 105-121.

Bonebrake, T.C., Ponisio, L.C., Boggs, C.L., Ehrlich, P.R. 2010. More than just indicators: a review of tropical butterfly ecology and conservation. Biological Conservation 143: 1831-1841.

Brown, K.S. 1992. Borboletas da Serra do Japi: diversidade, habitats, recursos alimentares e variação temporal. In: Morellato, L.P.C. (ed.). História natural da Serra do Japi: ecologia e preservação de uma área florestal no sudeste do Brasil. Unicamp, Campinas, Brasil, p. 142-186.

Brown, K.S., Freitas, A.V.L. 2000. Diversidade de Lepidoptera em Santa Tereza, Espírito Santo. Boletim do Museu de Biologia Mello Leitão 11/12: 71-118.

Collier, N., Gardner, M., Adams, M., Mcmahon, C.R., Benkendorff, K., Mackay, D.A. 2010. Contemporary habitat loss reduces genetic diversity in an ecologically specialized butterfly. Journal of Biogeography 37: 1277-1287.

Cunha, N.G.da., Silveira, R.J.daC., Koester, E., Oliveira, L.D.de., Alba, J.M.F., Terres, V.C., Lopes, R.T. 2011. Estudos de Solos do Município de Frederico Westphalen, RS. Circular técnica 116 : 1-32.

Filgueiras, B.K.C., Melo, D.H.A., Leal, I.R., Tabarelli, M. Freitas, A.V.L., lannuzzi, L. 2016. Fruitfeeding butterflies in edge-dominated habitats: community structure, species persistence and cascade effect. Journal of Insect Conservation
20: 539-548.

Freitas, A.V.L. 2010. Impactos potenciais das mudanças propostas no Código Florestal Brasileiro sobre as borboletas. Biota Neotropica 10: 53-58.

Giovenardi, R., Di Mare, R.A., Mielke, O.H.H., Casagrande, M.M., Carneiro, E. 2013. Mariposas de Rio Grande do Sul, Brasil (Lepidoptera: Papilionoidea, Hesperioidea). Revista Colombiana de Entomologia 39: 267-275.

Hammer, O., Harper, D.A.T., Ryan, P.D. 2001. Past: Paleontological Statistics Software Package for Education and Data Analysis. Palaeontologia Electronica 4: 1-9.

lbge. 2012. Manual técnico da vegetação brasileira. Coordenação de Recursos Naturais e Estudos Ambientais, Rio de Janeiro, Brasil. 271p.

Lamas, G. 2004. Checklist: Part 4A. HesperioidesPapilionoides. In: Heppner, J.B. (ed.). Atlas of Neotropical Lepidoptera. Association for Tropical Lepidoptera/Scientific Publishers, Gainesville, EUA, p. 1-439.

Leal, I.R., Wirth, R., Tabarelli, M. 2014. The multiple impacts of leafcutting ants and their novel ecological role in human-modified neotropical forests. Biotropica 46: 516-528.

Pedrotti, V.S., Barros, M.P.de., Romanowski, H.P., Iserhard, C.A. 2011. Borboletas frugívoras (Lepidoptera: Nymphalidae) ocorrentes em um fragmento de Floresta Ombrófila Mista no Rio Grande do Sul, Brasil. Biota Neotropica 11: 385390.

Reflora. Flora do Brasil 2020 em construção. Jardim Botânico do Rio de Janeiro. 2017. http:// floradobrasil.jbrj.gov.br/<Acesso em 22 Fev. 2017>

Ribeiro, D.B., Batista, R., Prado, P.I., Brown Jr., K.S., Freitas, A.V.L. 2012. The importance of small scales to the fruit-feeding butterfly assemblages in a fragmented landscape. Biodiversity and Conservation 21: 811-827.

Roman, M., Garlet, J., Costa, E.C. 2010. Levantamento populacional e comportamento de vôo de borboletas (Lepidoptera) em um remanescente florestal em São Sepé, RS. Ciência Florestal 20: 283-294.

Sant'anna, C.L.B., Ribeiro, D.B., Garcia, L.C., Freitas, A.V.L. 2014. Fruit-feeding butterfly communities are influenced by restoration age in tropical forests. Restoration Ecology 22: 480-485.

Santos, J.P., Marini-Filho, O.J., Freitas, A.V.L. Uehara-Prado, M. 2016. Monitoramento de borboletas: o papel de um indicador biológico 
na gestão de unidades de conservação. Biodiversidade Brasileira 6: 87-99.

Silva, J.M., Cunha, S.K.da., Silva, E.J.E.E, Garcia, F.R.M. 2013. Borboletas frugívoras (Lepidoptera: Nymphalidae) no Horto Botânico Irmão Teodoro Luis, Capão do Leão, Rio Grande do Sul, Brasil. Biotemas 26: 87-95.

Spaniol, R.L., Morais, A.B.B. 2015. Borboletas frugívoras em área de transição ecológica do sul do Brasil (Lepidoptera: Nymphalidae). SHILAP Revista de Lepidopterología 43: 27-40.

Tabarelli, M., Aguiar, A.V., Ribeiro, M.C., Metzger, J.P., Peres, C.A. 2010. Prospects for biodiversity conservation in the Atlantic forest: lessons for aging human-modified landscapes. Biological Conservation 143: 2328-2340.

Tropicos. Missouri Jardim Botânico. 2017. http:// www.tropicos.org/<Acesso em: 22 Fev. 2017>

Uehara-Prado, M., Brown, K.S., Freitas, A.V.L. 2007. Species richness, composition and abundance of fruit-feeding butterflies in the Brazilian Atlantic forest: comparison between a fragmented and a continuous landscape. Global Ecology and Biogeography 16: 43-54.

Wahlberg, N., Leneveu, J., Kodandaramaiah, U., Peña, C., Nylin, S., Freitas, A.V.L., Brower, A.V.Z. 2009. Nymphalid butterflies diversify following near demise at the Cretaceous/Tertiary boundary. Proceedings of the Royal Society Series B Biological Science 276: 4295-4302. 